\title{
Phosphorus limitation of primary productivity during the spring-summer blooms in Sagami Bay, Japan
}

\author{
Tetsuichi Fujiki ${ }^{1, *}$, Tatsuki Toda ${ }^{2}$, Tomohiko Kikuchi ${ }^{3}$, Hideki Aono ${ }^{3}$, \\ Satoru Taguchi ${ }^{2}$ \\ ${ }^{1}$ Hydrospheric Atmospheric Research Center, Nagoya University, Chikusa-ku, Nagoya 464-8601, Japan \\ ${ }^{2}$ Faculty of Engineering, Soka University, 1-236 Tangi-cho, Hachioji, Tokyo 192-8577, Japan \\ ${ }^{3}$ Faculty of Education and Human Sciences, Yokohama National University, 79-2 Tokiwadai, Hodogaya-Ku, \\ Yokohama 240-8501, Japan
}

\begin{abstract}
In coastal regions of Sagami Bay, Japan, we examined the nutrient limitations of primary productivity of phytoplankton blooms during spring to summer 2000, using 2 approaches; (1) dissolved nutrient concentrations and ratios, and (2) bioassay experiments. During the study period, maximum concentration of nitrate + nitrite $(19.2 \mu \mathrm{M})$ and silicate $(31.2 \mu \mathrm{M})$ were measured on July 10 after heavy rainfalls, where the supplies of nitrate, nitrite and silicate to the coastal regions primarily related to the increase in freshwater discharge by precipitation. However, such relationships were not found regarding the phosphate concentration. Chlorophyll (Chl) a concentration increased after the increase in freshwater discharge and Chl a peaks over $10 \mathrm{mg} \mathrm{m}^{-3}$ were observed 5 times. Phosphate concentration observed at the depth of the $5 \mathrm{Chl}$ a peaks was low enough to indicate probable $\mathrm{P}$ limitation based on criteria of nutrient concentrations and ratios. Bioassay experiments were carried out 12 times, every 8 d from May 1 to July 28. Primary productivities following nitrate and silicate additions showed no response compared to the controls. However, phosphate additions in the post-bloom period caused a significant increase in the primary productivity. On May 25 , the primary productivity increased $51 \%$ relative to the control. These results suggest that phytoplankton productivity was limited by phosphate during the spring-summer blooms, and that phosphate availability in the Sagami Bay is an important factor in the termination of the blooms.
\end{abstract}

KEY WORDS: Bioassay $\cdot$ Coastal ecosystem $\cdot$ Nutrient $\cdot$ P limitation $\cdot$ Phytoplankton bloom $\cdot$ Primary productivity

Resale or republication not permitted without written consent of the publisher

\section{INTRODUCTION}

Nitrogen (N), phosphorus (P) and silicon (Si) may potentially limit phytoplankton growth and primary productivity in aquatic systems (e.g. Ryther \& Dunstan 1971, Schindler 1977, Howarth 1988, Conley \& Malone 1992, Pitkänen \& Tamminen 1995). For many years, N was commonly believed to be the most important nutrient regulating the primary productivity in marine systems, while P limitation prevailed in freshwater systems (Howarth 1988). However, P limitation has also been reported in estuaries and coastal areas (Harrison et al. 1990, Turner et al. 1990, Thingstad et al. 1998, Labry et al. 2002), as well as in some oceanic regions (Krom et al. 1991, Karl et al. 1997). In estuarine and coastal regions, which are characterized by seasonally varying mixtures of fresh and seawater, there is evidence for seasonal and spatial variations in the limiting nutrient (D'Elia et al. 1986, Rudek et al. 1991, Del Amo et al. 1997).

A number of techniques have been employed in the past to determine factors limiting phytoplankton productivity (e.g. Howarth 1988, Beardall et al. 2001). The nutrient concentrations and ratios in the water in 
which the phytoplankton are growing are usually a logical starting point in detecting which nutrient may limit phytoplankton productivity. This approach alone could not give definitive conclusions about the actual limiting nutrient for phytoplankton productivity, because of the role of cellular nutrient storage and the turnover from nutrient regeneration (e.g. Currie \& Kalff 1984, Smith et al. 1985, Dodds \& Priscu 1990). However, this approach has been used as a latent index of nutrient limitation (Boynton et al. 1982, Justic et al. 1995, Del Amo et al. 1997). Bioassay experiments have been used as the dominant approach for examining nutrient limitations in estuaries and coastal waters (Ryther \& Dunstan 1971, D'Elia et al. 1986, Fisher et al. 1999, Holmboe et al. 1999). This technique includes addition of nutrients to bottles containing the phytoplankton assemblage, and then measurement of its effects on growth or production by monitoring biomass, chlorophyll (Chl) or isotope uptake in comparison with controls.

Sagami Bay, situated on the eastern coast of Japan, covers an area of $2700 \mathrm{~km}^{2}$ (Fig. 1). Nutrients are supplied to the bay through the upwelling of deep seawaters, the inflow of the eutrophic waters from the Tokyo Bay and the outflows from the 2 main rivers (Sakawa and Sagami) and other rivers. The eutrophic waters are mixed with the Kuroshio Current (oligotrophic waters) flowing into the Sagami Bay. The counterclockwise currents along the coast are dominant in the bay, although the circulation patterns change rapidly corresponding to the distribution of the Kuroshio Current (Hirano et al. 1977, Iwata 1985). Kamatani et al. (2000) reported that the concentrations and ratios of nitrate, phosphate and silicate measured in the middle of the Sagami Bay from 1993 to 1994 were similar to those observed in 1978. Hence, they concluded that the increase in nutrients due to coastal eutrophication is washed out to the open ocean by the presence of strong currents in the bay. However, since Sagami Bay adjoins very populated areas, large amounts of eutrophic waters from the rivers and Tokyo Bay flow into the coastal regions. The area of the present study, located on the western side of the bay, is particularly influenced by the eutrophic waters from the rivers. Earlier work conducted in the coastal regions during the period from 1995 to 1999 showed that the proportions of phytoplankton blooms observed between May and July increased as compared to those reported during the 1960 to 1980s (Satoh et al. 2000, Toda et al. 2000). There is no study assessing the relationship between nutrient conditions and phytoplankton bloom dynamics.

We present a study of the nutrient limitation of primary productivity during the spring-summer blooms in 2000 in the coastal regions of the Sagami Bay using 2 approaches: (1) concentrations and ratios of dissolved nutrients, and (2) bioassay experiments. The purpose of the present study was to determine the nutrients which are limiting primary productivity. The study of nutrient limitation of primary producers is important for water quality management in coastal environments because increasing the supply of a limiting nutrient may lead to severe eutrophication and deterioration of the water quality.

\section{MATERIALS AND METHODS}

Sampling procedures. Seawater samples were collected from depths of $0,2,5,10$ and $15 \mathrm{~m}$ at a sampling site $\left(35^{\circ} 09^{\prime} 30^{\prime \prime} \mathrm{N}, 139^{\circ} 09^{\prime} 25^{\prime \prime} \mathrm{E}\right.$, depth $\left.20 \mathrm{~m}\right)$ near the Manazuru Peninsula located in the Sagami Bay at about 09:00 h every second day between April 19 and July 30, 2000 (Fig. 1). The water temperature
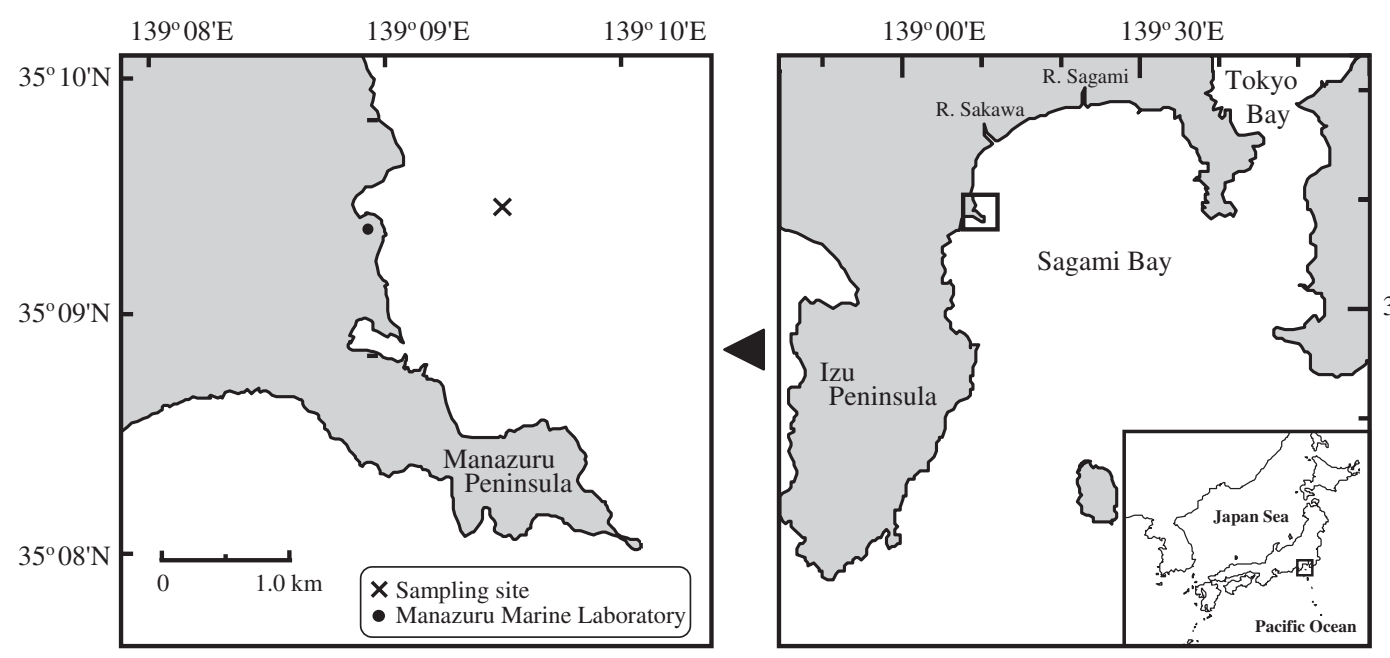

$35^{\circ} 00^{\prime} \mathrm{N}$

Fig. 1. Location of sampling site in Sagami Bay, Japan 
was measured with a mercury thermometer immediately on collection of the samples. Water samples were prescreened through a $333 \mu \mathrm{m}$ mesh to eliminate debris, and immediately transported to the Manazuru Marine Laboratory, Yokohama National University (Fig. 1). Salinity was measured using an inductive salinometer at the laboratory. Precipitation was measured every day during the investigated period with a rain gauge placed on the roof of the Manazuru Municipal Office.

Chlorophyll a concentration. Duplicate subsamples of $>100 \mathrm{ml}$ were filtered onto Whatman GF/F glass fiber filters for analysis of $\mathrm{Chl}$ a pigment. Each filter was extracted with $\mathrm{N}, \mathrm{N}$-dimethylformamide in the dark at $4^{\circ} \mathrm{C}$ for $24 \mathrm{~h}$ (Suzuki \& Ishimaru 1990). Chl a concentration was determined fluorometrically on a Turner Design fluorometer according to Holm-Hansen et al. (1965).

Nutrient analysis. Dissolved inorganic nutrient samples were filtered through Millipore Millex filters (pore size: $0.22 \mu \mathrm{m})$. The concentrations of nitrate + nitrite, phosphate and silicate were measured on the filtrate using a nutrient autoanalyzer (Bran + Luebbe, AACSII Compact System).

Using the combination of nutrient concentrations and ratios, the possibility of nutrient limitation can be assessed (Fisher et al. 1988, Dortch \& Whitledge 1992, Justic et al. 1995). If the ambient concentration of a nutrient is less than the upper range of the half-saturation constant for uptake, phytoplankton is limited by that nutrient (Fisher et al. 1988). According to Dortch \& Whitledge (1992) and Justic et al. (1995), when concentrations of dissolved inorganic nitrogen (DIN; nitrate, nitrite and ammonium), phosphate and silicate are $<1.0,0.2$ and $2.0 \mu \mathrm{M}$, respectively, they are then considered limiting. For estimating which nutrient will be depleted first, we calculated the molar ratios of nutrients. Based on Dortch \& Whitledge (1992) and Justic et al. (1995), we applied the following criteria: (a) Si limitation if $\mathrm{Si} / \mathrm{P}<10$ and $\mathrm{Si} / \mathrm{DIN}<1$; (b) N limitation if DIN/P $<10$ and Si/DIN $>1$; (c) P limitation if $\mathrm{Si} / \mathrm{P}>20$ and DIN/P $>20$. However, if the concentration of the particular nutrient is greater than the halfsaturation constant for uptake, then limitation by the nutrient is ruled out. If concentration of that nutrient is less, then probable limitation is suggested (Dortch \& Whitledge 1992). Ammonium concentration was not measured in the present study. According to Hattori (1977), seasonal variation of ammonium concentration in water less than $50 \mathrm{~m}$ deep in the Sagami Bay was 0.1 to $3 \mu \mathrm{M}$ and averaged $0.5 \mu \mathrm{M}$, and ammonium was a prevailing component of DIN when the concentration of DIN was low. Hence, for this study, we assumed that ammonium concentration was $0.5 \mu \mathrm{M}$ for assessing nutrient limitation.
Bioassays. To assess nutrient limitation of primary productivity during the phytoplankton blooms, the bioassay experiments were carried out every $8 \mathrm{~d}$ from May 1 to July 28, 2000. Subsamples collected from the surface water at about 09:00 $\mathrm{h}$ were transferred into 41 polycarbonate bottles. The bioassay treatments included the addition of $26.4 \mu \mathrm{M} \mathrm{NaNO}, 2.52 \mu \mathrm{M}$ $\mathrm{NaH}_{2} \mathrm{PO}_{4}$ or $36.7 \mu \mathrm{M} \mathrm{Na} \mathrm{SiO}_{3}$, along with controls without nutrient addition. Duplicates were made for each treatment. The addition of nutrients were done according to Holmboe et al. (1999), so that the concentrations were nearly 2 -fold compared to the maximum concentrations observed at this location during the spring-summer of the previous year. The bioassays were incubated under natural surface light for $24 \mathrm{~h}$ with addition of ${ }^{13} \mathrm{C}-\mathrm{NaHCO}_{3}$ (final ${ }^{13} \mathrm{C}$ atom\% in dissolved inorganic carbon was $\sim 10 \%$; Hama et al. 1983). The bottles were floated in the aquarium and gently shaken by hand every $4 \mathrm{~h}$ during the incubations. Water temperature was controlled to the surface water temperature at the sampling site. After the incubation, duplicate aliquots of $>200 \mathrm{ml}$ were filtered through pre-combusted $\left(450^{\circ} \mathrm{C}, 4 \mathrm{~h}\right) \mathrm{GF} / \mathrm{F}$ filters. The filters were stored at $-20^{\circ} \mathrm{C}$ until analysis. The filters were treated with $\mathrm{HCl}$ fumes for $2 \mathrm{~h}$ to remove carbonate and dried at $54^{\circ} \mathrm{C}$ over $12 \mathrm{~h}$. The concentration of particulate organic carbon and the isotopic ratios of ${ }^{13} \mathrm{C}$ and ${ }^{12} \mathrm{C}$ were measured by a mass spectrometer (Finnigan MAT, TracerMAT) combined with an elemental analyzer (Fisons, Instruments NA-1500). Primary productivity of phytoplankton was calculated according to Hama et al. (1983). The nutrient limitation was assessed by comparing primary productivity of each treatment with the controls.

Short-term bioassay experiments of nutrient additions have some shortcomings. Healey (1979) showed that bioassay experiments over several hours did not stimulate phytoplankton productivity because of delays of the response to nutrient additions. For this reason, short-term bioassay experiments with natural phytoplankton for monitoring nutrient limitation in coastal waters have been run for more than $15 \mathrm{~h}$ for the phytoplankton to physiologically adapt to nutrient additions (Nyholm \& Lyngby 1988, Holmboe et al. 1999). However, physical long-term enclosure of a natural phytoplankton assemblage for more than $1 \mathrm{~d}$ can have noxious effects upon the physiological performance and result in changes in the species composition of the phytoplankton assemblage (e.g. Venrick et al. 1977). Thus, short-term bioassay experiments of this study were carried out for a $24 \mathrm{~h}$ time period.

Statistical analysis. Tests for differences between means were carried out using $t$-tests (Kyplot 3.0, Kyence). The level of significance was set as $p<0.05$ for all statistical analyses. 


\section{RESULTS}

\section{Abiotic factors}

As the season progressed from spring to summer, water temperature increased from $15^{\circ} \mathrm{C}$ in late April to $26^{\circ} \mathrm{C}$ at the end of July (Fig. 2b). The water column was substantially homogeneous until the end of May and frequently stratified from June. The highest value of precipitation was $120 \mathrm{~mm}$. It was measured on July 7 at the end of the rainy season, which extends from the middle of June to the beginning of July (Fig. 2a). Continuous precipitation with a total amount of $113 \mathrm{~mm}$ was recorded during the period from June 11 to 14, at the beginning of the rainy season. Salinity varied ranging from 28.7 to 35.6 PSU and was below 33 PSU during the rainy season (Fig. 2c).

There was a large temporal variation in dissolved inorganic nutrients. The highest nitrate + nitrite $(19.2 \mu \mathrm{M})$ and silicate $(31.2 \mu \mathrm{M})$ concentrations were measured on July 10 after heavy rainfalls (Fig. 2d,f). The influence of precipitation on nitrate + nitrite and silicate concentrations was indicated by significant relationships in which the concentrations were highest when the salinity was lowest and declined with increasing salinity ( $p<0.001$, Fig. 3a,c). In contrast, the highest phosphate concentration $(0.64 \mu \mathrm{M})$ was observed on June 22 although it did not rain from June 17 to 22 (Fig. 2a,e). There was no significant relationship between salinity and phosphate concentration (Fig. 3b).

Phosphate concentration was below the half-saturation constant for uptake in $53 \%$ of the samples, whereas silicate and DIN (nitrate + nitrite + ammonium) concentrations were below the half-saturation constant in only 14 and $6.5 \%$, respectively (Table 1 ). Furthermore, according to the more stringent criteria of combining nutrient concentrations and ratios, probable $\mathrm{P}$ limitation occurred in $25 \%$ of the samples in this study (Table 1 ).

\section{Biomass}

Chl a peaks with values over $10 \mathrm{mg}$ $\mathrm{m}^{-3}$ were observed 5 times during the period of sampling (Fig. 2g). Four peaks in May to June were found at the depth of 0 to $2 \mathrm{~m}$, but the other peak in July was measured at the depth of $5 \mathrm{~m}$. Based on the spatial and temporal variations in Chl a concentration, we divided the phytoplankton blooms into 5 phases, indicated by Roman numerals in Fig. 2g. The divi-
Table 1. Percentage of all samples $(n=275)$, in which nutrient concenrations and ratios suggest nutrient limitation, using 2 criteria to assess mitation. All concentrations in $\mu \mathrm{M}_{\text {; }}$ all ratios on molar basis. DIN: dissolved inorganic nitrogen (nitrate, nitrite, ammonium)

\begin{tabular}{lccc} 
& $\mathrm{SiO}_{4}$ & $\mathrm{DIN}^{*}$ & $\mathrm{PO}_{4}$ \\
\hline Nutrient concentrations $^{\mathrm{a}}$ & 14.3 & 6.5 & 52.7 \\
Nutrient concentrations and ratios & 4.9 & 2.0 & 25.0 \\
& & \\
& \\
&
\end{tabular}

sions based on the Chl a concentration were supported by the results of microscopic examination of samples collected in conjunction with this study (Aono 2001, Miyaguchi 2003). The phytoplankton assemblages in phase II were dominated by dinoflagellates, Ceratium furca and Ceratium fusus. Phytoplankton assemblages during the other phases were dominated almost entirely by diatoms such as Nitzschia spp., Thalassiosira spp. and Chaetoceros spp. In addition, a high population density of Noctiluca scintillans, a heterotrophic dinoflagellate, was observed during May.

During the course of spring and summer, increases of Chl a concentration were observed after nutrient input to the bay (Fig. $2 \mathrm{~d}-\mathrm{g}$ ). Nutrient concentrations decreased with increasing $\mathrm{Chl} a$ concentration. For instance, the concentrations of silicate, DIN and phosphate at $0 \mathrm{~m}$ on May 21 were 7.50, 4.07 and $0.11 \mu \mathrm{M}(\mathrm{Si}: \mathrm{N}: \mathrm{P}=69: 38: 1)$, respectively, when the highest concentration of $\mathrm{Chl} a$ (23.1 $\mathrm{mg} \mathrm{m}^{-3}$ ) was observed (Table 2). The phosphate concentration decreased below the half-saturation constant for uptake. At the depth of $\mathrm{Chl}$ a peaks it was low enough to indicate probable $\mathrm{P}$ limitation in all phases, except in phase IV $\left(\mathrm{PO}_{4}=0.44 \mu \mathrm{M}\right)$ (Table 2$)$.

\section{Bioassays}

In the 12 bioassay experiments, Chl a-specific primary productivity of controls without nutrient addition varied about 3.6-fold and ranged from 14.7 to $52.8 \mathrm{mg} \mathrm{C}$
Table 2. Concentrations and ratios of dissolved nutrients observed at the depth of $\mathrm{Chl}$ a peaks in 5 phases

\begin{tabular}{|c|c|c|c|c|c|c|c|c|}
\hline Phase & Date & $\begin{array}{l}\text { Depth } \\
\text { (m) }\end{array}$ & $\begin{array}{c}\mathrm{Chl} \mathrm{a} \\
\left(\mathrm{mg} \mathrm{m}^{-3}\right)\end{array}$ & $\begin{array}{c}\text { Conce } \\
\mathrm{SiO}_{4}\end{array}$ & $\begin{array}{l}\text { atratio } \\
\text { DIN }\end{array}$ & $\begin{array}{l}\text { as }(\mu \mathrm{M}) \\
\mathrm{PO}_{4}\end{array}$ & $\begin{array}{c}\text { Ratio } \\
\text { Si : N : P }\end{array}$ & $\begin{array}{l}\text { Probable } \\
\text { limitation }\end{array}$ \\
\hline I & May 7 & 2 & 15.0 & 4.55 & 1.87 & 0.06 & $80: 33: 1$ & $\mathrm{P}$ \\
\hline II & May 21 & 0 & 23.1 & 7.50 & 4.07 & 0.11 & $69: 38: 1$ & $\mathrm{P}$ \\
\hline III & May 31 & 0 & 12.4 & 4.85 & 3.41 & 0.13 & $37: 26: 1$ & $\mathrm{P}$ \\
\hline IV & Jun 22 & 2 & 17.5 & 12.1 & 9.02 & 0.44 & $28: 21: 1$ & - \\
\hline V & Jul 12 & 5 & 11.0 & 5.06 & 3.38 & 0.14 & $36: 24: 1$ & $\mathrm{P}$ \\
\hline
\end{tabular}




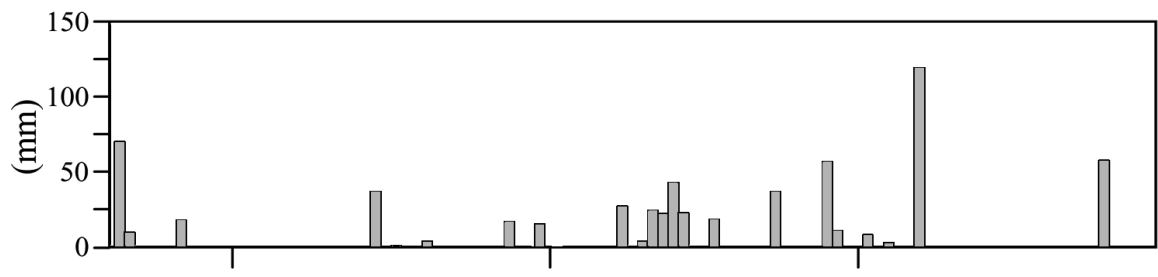

(a) precipitation

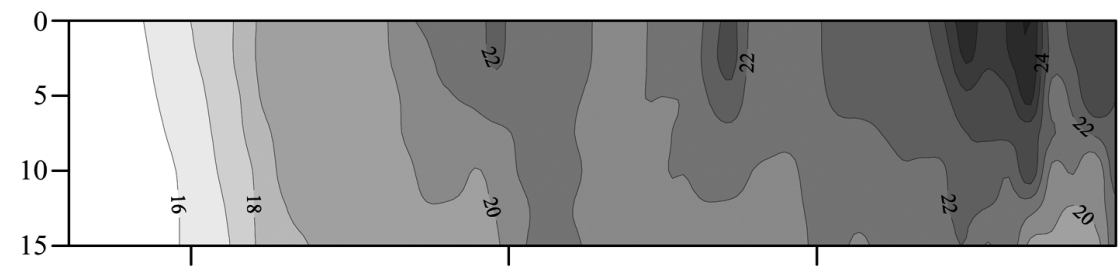

(b) temperature

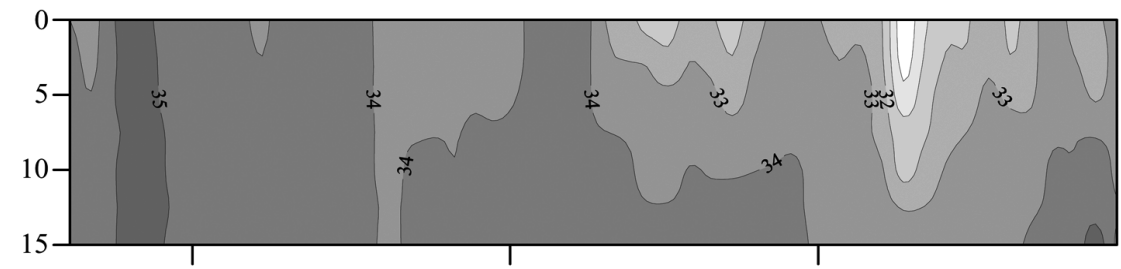

(c) salinity

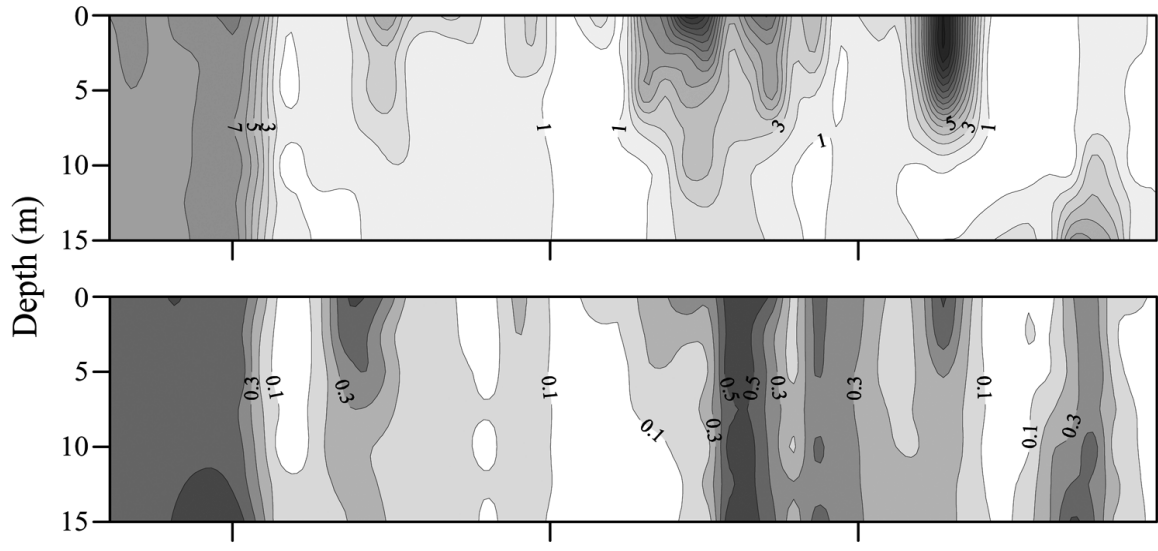

(d) nitrate

+ nitrite

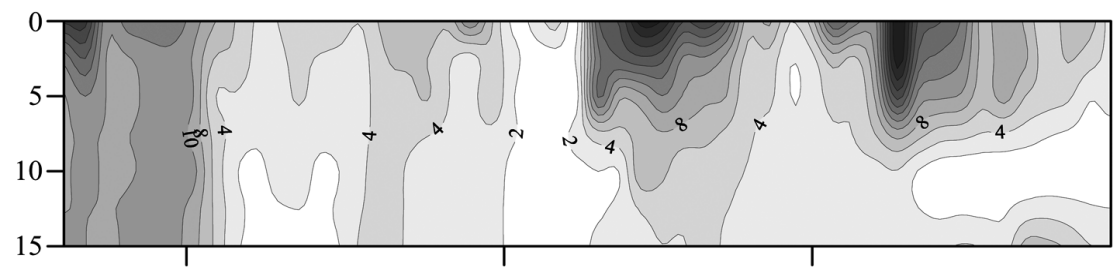

(f) silicate

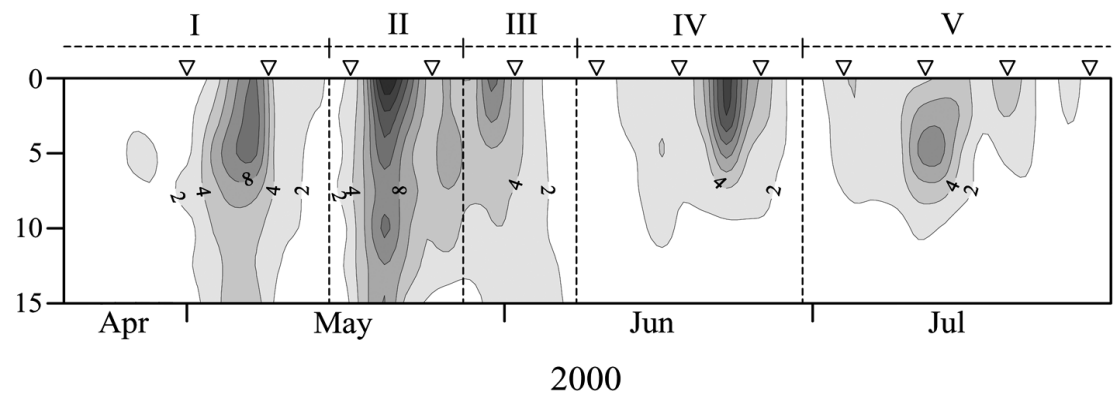

(g) chlorophyll $a$

Fig. 2. Temporal variations in (a) daily precipitation $(\mathrm{mm})$, (b) temperature $\left({ }^{\circ} \mathrm{C}\right),(\mathrm{c})$ salinity $(\mathrm{PSU})$, (d) nitrate + nitrite $(\mu \mathrm{M})$, (e) phosphate $(\mu \mathrm{M})$, (f) silicate $(\mu \mathrm{M})$ and $(\mathrm{g})$ chlorophyll $a\left(\mathrm{mg} \mathrm{m}^{-3}\right)$ at the sampling site from April 19 to July 30, 2000. (g) Phytoplankton blooms are divided into 5 phases based on the spatial and temporal variations in Chl $a$ concentrations. $\nabla$ : days on which bioassay experiments were carried out 
mgChl $a^{-1} \mathrm{~d}^{-1}$ (Table 3). The mean Chl a-specific primary productivity was significantly lower when $\mathrm{P}$ was limiting $\left(27.2 \pm 10.8 \mathrm{mgC} \mathrm{mgChl} \mathrm{a}^{-1} \mathrm{~d}^{-1}\right)$ than when

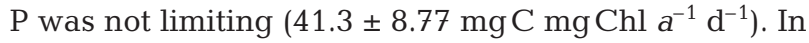
the 12 bioassay experiments, phytoplankton assemblages responded differently to the nutrient treatments (Table 3). Compared to the controls, the relative primary productivities of nitrate and silicate additions were $102 \pm 8.8$ and $101 \pm 5.3 \%$, respectively. The nitrate and silicate additions gave no responses, except on June 2. Concentrations of silicate, DIN and phosphate on June 2 were $0.91,0.95$ and $0.05 \mu \mathrm{M}$, respectively, and all concentrations were below the halfsaturation constant for uptake. The relative primary
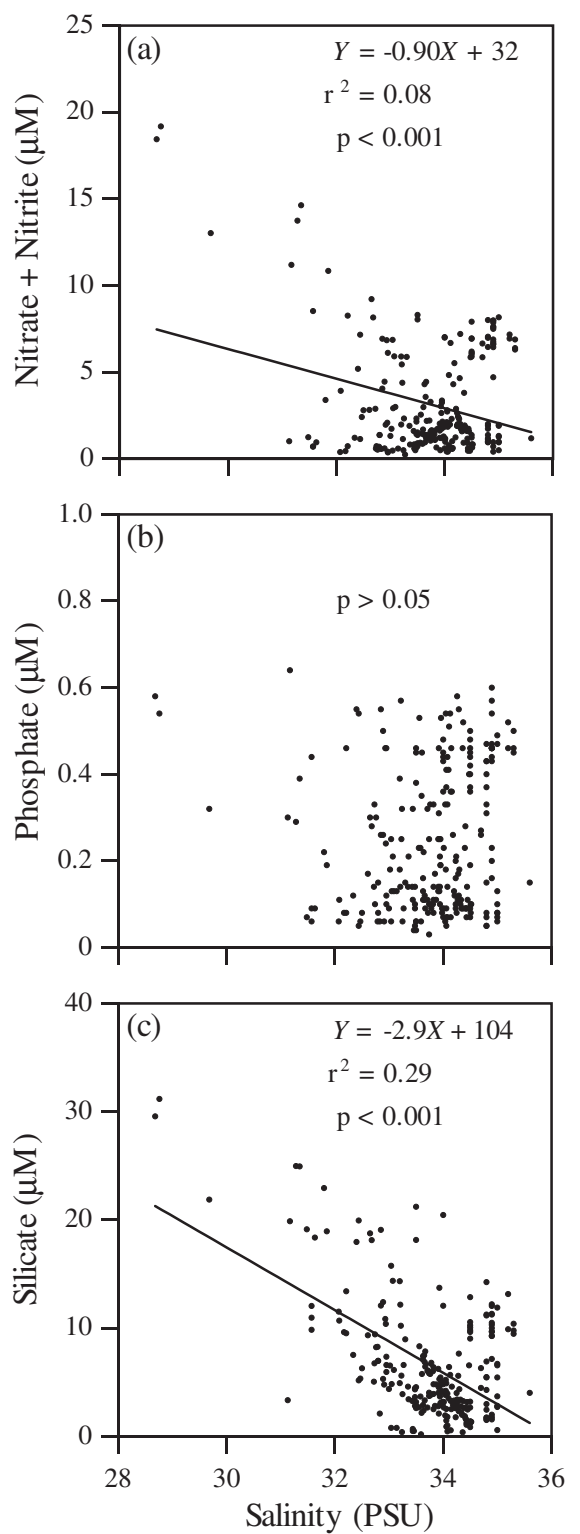

Fig. 3. Relationships between salinity and (a) nitrate + nitrite, (b) phosphate and (c) silicate concentrations productivity in case of phosphate addition was $118 \pm 17 \%$, and there was considerable temporal variability in the bioassay results for phosphate addition. On May 9 and 25, June 2 and July 20 and 28 when Chl a-specific primary productivity of controls was lower than $30 \mathrm{mg} \mathrm{C} \mathrm{mg} \mathrm{Chl} a^{-1} \mathrm{~d}^{-1}$ and phosphate concentration was below the half-saturation constant for uptake, the phosphate addition caused over $20 \%$ gain of primary productivity compared to the controls. The largest increase was observed on May 25, with the primary productivity gaining over $51 \%$. The mean relative primary productivities were significantly different $(p<0.01)$ for the P-limited $(1.30 \pm 0.15)$ and P-unlimited bioassay experiments $(1.05 \pm 0.08)$.

\section{DISCUSSION}

In this study, occasional increases in freshwater discharge due to precipitation resulted in large loadings of $\mathrm{N}$ and $\mathrm{Si}$ to the coastal waters but not P (Fig. 2a,d-f). As high concentrations of phosphate were observed several times at the bottom layer, phosphate may have been primarily supplied by release from the coastal sediment. The available $\mathrm{P}$ in the system was quickly used up by phytoplankton with excess of $\mathrm{N}$ and $\mathrm{Si}$ supplied by river outflow. Consequently, increase in $\mathrm{N}$ and $\mathrm{Si}$ driven by precipitation created P deficiency in the coastal regions of the Sagami Bay. This interpretation agrees with the consideration by Howarth (1988) that the variation in nutrient limitation is dependent on different nutrient loading ratios.

Phytoplankton assemblages had consumed and exhausted phosphate in the coastal regions since phosphate concentrations measured during almost all $\mathrm{Chl} a$ peaks were low enough to indicate probable P limitation (Table 2). In this study, an additional approach to determine nutrient limitation was conducted with the bioassay experiments, which provides information about actual nutrient limitation of the primary productivity. Until now, some studies demonstrated P limitation in estuaries and coastal regions using long-term bioassay experiments of several days (Harrison et al. 1990, Fisher et al. 1999, Labry et al. 2002). Short-term bioassay experiments carried out by Holmboe et al. (1999) revealed that the primary productivity following phosphate addition in P limited estuary increased by $20 \%$ compared to the control. In the present study, the relative primary productivity following phosphate additions increased over $20 \%$ when phosphate concentration was below the half-saturation constant for uptake (Table 3). In 4 out of 5 occasions, nutrient limitation verified by the bioassay experiments corresponded well with the nutrient limitation predicted from the concentrations. On June 2, when all 3 nutri- 
Table 3. Nutrient concentrations on dates for bioassay experiments and the variation of primary productivity following the nutrient additions. The mean $( \pm \mathrm{SD})$ for each parameter was calculated for all samples when $\mathrm{P}$ was limiting and when $\mathrm{P}$ was not limiting, using ambient $\mathrm{PO}_{4}<0.2 \mu \mathrm{M}$ as an indicator

\begin{tabular}{|c|c|c|c|c|c|c|c|}
\hline \multirow[t]{2}{*}{ Date } & \multicolumn{3}{|c|}{ Concentrations $(\mu \mathrm{M})$} & \multirow{2}{*}{$\begin{array}{c}\text { Control } \\
\left(\mathrm{mgC} \mathrm{mgChl} \mathrm{a} \mathrm{a}^{-1} \mathrm{~d}^{-1}\right)\end{array}$} & \multirow{2}{*}{\multicolumn{3}{|c|}{$\begin{array}{c}+\mathrm{N} \\
\text { (normalized to control) }\end{array}$}} \\
\hline & $\mathrm{SiO}_{4}$ & DIN & $\mathrm{PO}_{4}$ & & & & \\
\hline May 1 & 11.9 & 8.66 & 0.49 & 40.2 & 1.01 & 1.09 & 1.07 \\
\hline May 9 & 3.00 & 1.66 & $0.05^{\mathrm{a}}$ & 29.7 & 1.06 & 0.99 & 1.38 \\
\hline May 17 & 2.94 & 6.01 & 0.26 & 52.8 & 0.99 & 0.99 & 1.02 \\
\hline May 25 & 7.85 & 2.68 & $0.09^{\mathrm{a}}$ & 28.5 & 1.03 & 1.04 & 1.51 \\
\hline June 2 & $0.91^{\mathrm{a}}$ & $0.95^{\mathrm{a}}$ & $0.05^{\mathrm{a}}$ & 14.7 & 1.14 & 1.24 & 1.31 \\
\hline June 10 & 15.8 & 7.36 & 0.25 & 49.8 & 1.03 & 1.03 & 0.97 \\
\hline June 18 & 18.0 & 5.69 & 0.55 & 39.4 & 0.96 & 0.96 & 1.15 \\
\hline June 26 & 10.9 & 7.34 & 0.46 & 29.0 & 0.97 & 0.96 & 0.97 \\
\hline July 4 & 23.0 & 3.89 & 0.22 & 36.5 & 1.00 & 1.03 & 1.13 \\
\hline July 12 & 10.7 & 4.42 & $0.11^{\mathrm{a}}$ & 46.3 & 0.96 & 0.99 & 1.07 \\
\hline July 20 & 11.0 & 1.20 & $0.06^{\mathrm{a}}$ & 20.9 & 0.97 & 0.88 & 1.30 \\
\hline July 28 & 6.98 & 1.87 & $0.15^{\mathrm{a}}$ & 23.0 & 0.95 & 1.02 & 1.22 \\
\hline P-limited & $6.74 \pm 4.08$ & $2.13 \pm 1.27$ & $0.09 \pm 0.04$ & $27.2 \pm 10.8$ & $1.02 \pm 0.07$ & $1.03 \pm 0.12$ & $1.30 \pm 0.15$ \\
\hline P-unlimited & $13.8 \pm 6.87$ & $6.49 \pm 1.66$ & $0.37 \pm 0.14$ & $41.3 \pm 8.77$ & $0.99 \pm 0.02$ & $1.01 \pm 0.05$ & $1.05 \pm 0.08$ \\
\hline
\end{tabular}

ents were below the half-saturation constant for uptake, all the nutrient additions caused a rise in the primary productivity. When phytoplankton productivity is limited simultaneously by several nutrients, combined nutrient addition produces significantly higher productivity response than a single nutrient addition (Gerhart \& Likens 1974, Elser et al. 1990, Fisher et al. 1999). As primary productivity on June 2 was limited by the 3 nutrients, the productivity response to the single nutrient addition may have declined.

The one exception was on July 12 when phosphate concentrations were below the half-saturation constant for uptake, while Chl a-specific primary productivity of controls was as high as $46.3 \mathrm{mgC} \mathrm{mgChl} \mathrm{a}^{-1} \mathrm{~d}^{-1}$ and the primary productivity following phosphate addition showed no response. This exception may have been due to the role of cellular P storage (e.g. Gotham \& Rhee 1981, Vincent 1981, Currie \& Kalff 1984). As temporal variability in the responses to phosphate additions was observed, we divided all bioassay data into 2 periods based on before and after $\mathrm{Chl}$ a peaks in the 5 phases; the pre-bloom period (May 1, 17, June 10, 18, July 4, 12) and the post-bloom period (May 9, 25, June 2, 26, July 20, 28) (Table 4). During the pre-bloom period, primary productivity of all nutrient treatments compared to the controls remained constant and therefore nutrient limitations were not likely to occur. Phosphate additions on the post-bloom period caused a positive effect on primary productivity compared to the controls, and the primary productivities following phosphate additions were significantly different in pre-bloom and post-bloom periods $(\mathrm{p}<0.05)$. Thus, the results showed that the primary productivity in the post-bloom period was limited by phosphate.
As a common feature in many coastal ecosystems, the onset of the high productive period is driven by physical factors, such as freshwater discharge and increase of light availability (Legendre et al. 1986, Peterson 1986, Tsuda et al. 1994, Del Amo et al. 1997). At a sampling site on the eastern coastal side of the bay, Furota (1980) observed a positive linear relationship between Chl a concentration and water column stability as also described by Sverdrup et al. (1942). In this study, the water column stability of $>0.1 \mathrm{~kg} \mathrm{~m}^{-2}$ was observed at the 4 peaks of Chl a except on May 21 (data not shown). The increase in Chl a concentrations was observed after about 2 to $6 \mathrm{~d}$ following freshwater discharge by precipitation (Fig 2a,g). However, in the middle of June, Chl a concentration remained low despite the large addition of nutrients by heavy precipitation. The reason may be due to the shortage of light (the mean daily irradiance of $23.2 \mathrm{~mol} \mathrm{~m}^{-2} \mathrm{~d}^{-1}$, see Fujiki et al. 2003). These results suggest that the development of phytoplankton blooms in the coastal regions probably requires increased light availability and a

Table 4. Comparisons of relative primary productivity $(\%$, normalized to controls) between pre-bloom and post-bloom periods. All bioassay data were divided into 2 periods based on before and after $\mathrm{Chl}$ a peaks in the 5 phases. Pre-bloom period; May 1, 17, June 10, 18, July 4, 12. Post-bloom period; May 9, 25, June 2, 26, July 20, 28. NS: not significant

\begin{tabular}{|lrcc|}
\hline Addition & Pre-bloom & Post-bloom & $\mathrm{p}(t$-test $)$ \\
\hline Nitrate & $101 \pm 4.4$ & $102 \pm 12$ & $\mathrm{NS}$ \\
Phosphate & $107 \pm 6.7$ & $128 \pm 18$ & $<0.05$ \\
Silicate & $99 \pm 2.6$ & $102 \pm 7.0$ & $\mathrm{NS}$ \\
\hline
\end{tabular}


stabilized water column, subsequent to the nutrient additions by precipitation.

Phytoplankton assemblages during the spring and summer of 2000 were dominated mainly by diatoms such as Nitzschia spp., Thalassiosira spp. and Chaetoceros spp. (Aono 2001, Miyaguchi 2003). High silicate concentrations characterized the coastal regions of the Sagami Bay during this period. The mean silicate concentration during this period was as high as $6.56 \pm$ $5.52 \mu \mathrm{M}$, and was higher than the half saturation constant for silicate uptake in diatoms $(2 \mu \mathrm{M})$. According to Egge \& Aksnes (1992), diatoms can continue to grow as long as the silicate concentration is above $2 \mu \mathrm{M}$. As the silicate concentration was $>2 \mu \mathrm{M}$ during most of the study period, silicate was not limiting diatom growth in this area. Therefore, diatoms dominate the phytoplankton community in the coastal regions of the Sagami Bay. The results of this study agree with the consideration by Kamatani et al. (2000) that the sufficient supply of silicate by the upwelling of sub-surface waters and/or by the riverine waters is favorable for the maintenance of diatom ecosystems in the Sagami Bay. However, in the present study, regardless of the high silicate concentration, the phytoplankton assemblages in phase II, when maximum Chl a concentration was encountered, were dominated by dinoflagellates, Ceratium furca and Ceratium fusus. Satoh et al. (2000) reported that the blooms were mainly composed of Ceratium furca in this coastal region. The reason for Ceratium spp. dominance needs to be examined in greater detail.

Phytoplankton productivity in the middle of the Sagami Bay is particularly influenced by the upwelling of deep seawaters or branches of the Kuroshio Current (oligotrophic waters). The ratios of nutrients supplied to the regions through the upwelling of deep seawaters were approximately 25:15:1 (Si:N:P) (Kamatani et al. 1977, 2000). Thus, nitrate was the most deficient nutrient during the main growth period of phytoplankton. However, as the coastal regions were influenced strongly by eutrophic waters, including large amounts of nitrate and silicate, the phytoplankton productivity was limited by phosphate. Moreover, the results of the present study suggest that the phosphate distribution in coastal regions of the Sagami Bay is one of the important factors in controlling spring-summer phytoplankton bloom dynamics. Phytoplankton productivity is generally regarded to be limited by nitrogen in marine waters (Ryther \& Dunstan 1971, Howarth 1988). Turner et al. $(2003 a, b)$ recently reviewed data for dissolved inorganic nitrogen, dissolved inorganic phosphate and dissolved silicate in the world's largest rivers. They proposed that nutrient limitation of phytoplankton growth in estuaries and coastal waters is moving towards a higher incident of $\mathrm{P}$ and/or Si limita- tion as a result of increased $\mathrm{N}$ loading, and the change in nutrient proportions will influence the growth and composition of aquatic food webs. Our results probably suggest that the coastal region of the Sagami Bay is one of the aquatic systems with changing nutrient proportions.

The aquatic ecosystems in coastal regions are more susceptible to anthropogenic disturbance and landsource pollution than those of the open sea. Above all, the eutrophication of costal waters can lead to increase in the proportions of algal blooms, and result in the degradation of water quality and the loss of habitat for the biota. In the present study, we cannot conclude that the variations of nutrient distributions relate to the recent increase in proportion of phytoplankton blooms in the coastal regions of the Sagami Bay (Satoh et al. 2000, Toda et al. 2000) because of the paucity of historical data on nutrient distributions in the coastal regions. For assessing the relevance, more studies are necessary to identify the sources and the supply rates of $\mathrm{P}$ into the coastal waters. This identification can provide important information for the prediction of phytoplankton biomass and the management of aquatic ecosystems in the Sagami Bay in the future.

Acknowledgements. We express our gratitude to E. Nishi and the staff at Manazuru Marine Laboratory for Science Education, Yokohama National University, for their cooperation and support in collecting samples. We are grateful to F. Chai and S. S. Mitbavkar for many helpful comments on this manuscript.

\section{LITERATURE CITED}

Aono H (2001) The changing process of phytoplankton communities during the spring bloom in Sagami Bay, central Japan. Masters thesis, Yokohama National University, Yokohama (in Japanese)

Beardall J, Young E, Roberts S (2001) Approaches for determining phytoplankton nutrient limitation. Aquat Sci 63: $44-69$

Boynton WR, Kemp WM, Keefe CW (1982) A comparative analysis of nutrients and other factors influencing estuarine phytoplankton production. In: Kennedy VS (ed) Estuarine comparisons. Academic Press, New York, p 69-90

Conley DJ, Malone TC (1992) Annual cycle of dissolved silicate in Chesapeake Bay: implications for the production and fate of phytoplankton biomass. Mar Ecol Prog Ser 81: $121-128$

Currie DJ, Kalff J (1984) The relative importance of bacterioplankton and phytoplankton in phosphorus uptake in freshwater. Limnol Oceanogr 29:311-321

Del Amo Y, Pape OL, Tréguer P, Quéguiner B, Ménesguen A, Aminot A (1997) Impacts of high-nitrate freshwater inputs on macrotidal ecosystems. I. Seasonal evolution of nutrient limitation for the diatom-dominated phytoplankton of the Bay of Brest (France). Mar Ecol Prog Ser 161:213-224

D'Elia CF, Sanders JG, Boynton WR (1986) Nutrient enrichment studies in a coastal plain estuary: phytoplankton growth in large-scale, continuous cultures. Can J Fish Aquat Sci 43:397-406 
Dodds WK, Priscu JC (1990) A comparison of methods for assessment of nutrient deficiency of phytoplankton in a large oligotrophic lake. Can J Fish Aquat Sci 47: 2328-2338

Dortch Q, Whitledge TE (1992) Does nitrogen or silicon limit phytoplankton production in the Mississippi River plume and nearby regions? Cont Shelf Res 12:1293-1309

Egge JK, Aksnes DL (1992) Silicate as regulating nutrient in phytoplankton competition. Mar Ecol Prog Ser 83:281-289

Elser JJ, Marzolf ER, Goldman CR (1990) Phosphorus and nitrogen limitation of phytoplankton growth in the freshwaters of North America: a review and critique of experimental enrichments. Can J Fish Aquat Sci 47:1468-1477

Fisher TR, Harding LW Jr, Stanley DW, Ward LG (1988) Phytoplankton, nutrients, and turbidity in the Chesapeake, Delaware, and Hudson estuaries. Estuar Coast Shelf Sci 27:61-93

Fisher TR, Gustafson AB, Sellner K, Lacouture R and 6 others (1999) Spatial and temporal variation of resource limitation in Chesapeake Bay. Mar Biol 133:763-778

Fujiki T, Toda T, Kikuchi T, Taguchi S (2003) Photoprotective response of xanthophyll pigments during phytoplankton blooms in Sagami Bay, Japan. J Plankton Res 25:317-322

Furota T (1980) Seasonal variation of phytoplankton standing stocks in temperate embayments. Jpn Bull Plankton Soc 27:63-73 (in Japanese)

Gerhart DZ, Likens GE (1975) Enrichment experiments for determining nutrient limitation: four methods compared. Limnol Oceanogr 20:649-653

Gotham IJ, Rhee GY (1981) Comparative kinetics studies of phosphate-limited growth and phosphate uptake in phytoplankton in continuous culture. J Phycol 17:257-265

Hama T, Miyazaki T, Ogawa Y, Iwakuma T, Takahashi M, Otsuki A, Ichimura S (1983) Measurement of photosynthetic production of a marine phytoplankton population using a stable ${ }^{13} \mathrm{C}$ isotope. Mar Biol 73:31-36

Harrison PJ, Hu MH, Yang YP, Lu X (1990) Phosphate limitation in estuarine and coastal waters of China. J Exp Mar Biol Ecol 140:79-87

Hattori A (1977) Detailed distribution and cycling of nitrogen in Sagami and Suruga Bays. In: Hogetsu K, Hatanaka M, Hanaoka T, Kawamura T (eds) Productivity of biocenoses in coastal regions of Japan, JIBP synthesis 14. University of Tokyo Press, Tokyo, p 42-48

Healey FP (1979) Short-term responses of nutrient-deficient algae to nutrient addition. J Phycol 15:289-299

Hirano T, Uehara S, Iwata S, Nakamura Y (1977) Suruga Bay and Sagami Bay: hydrographic conditions. In: Hogetsu K, Hatanaka M, Hanaoka T, Kawamura T (eds) Productivity of biocenoses in coastal regions of Japan, JIBP synthesis 14. University of Tokyo Press, Tokyo, p 31-37

Holmboe N, Jensen HS, Andersen FO (1999) Nutrient addition bioassays as indicators of nutrient limitation of phytoplankton in an eutrophic estuary. Mar Ecol Prog Ser 186:95-104

Holm-Hansen O, Lorenzen CJ, Holmes RW, Strickland JDH (1965) Fluorometric determination of chlorophyll. J Cons Perm Int Explor Mer 30:3-15

Howarth RW (1988) Nutrient limitation of net primary production in marine ecosystems. Annu Rev Ecol Syst 19:89-110

Iwata S (1985) Sagami Bay: physics. In: Oceanographical Society of Japan (ed) Coastal oceanography of Japanese Islands. Tokai University Press, Tokyo, p 401-409 (in Japanese)

Justic D, Rabalais NN, Turner RE, Dortch Q (1995) Changes in nutrient structure of river-dominated coastal waters: stoichiometric nutrient balance and its consequences. Estuar Coast Shelf Sci 40:339-356
Kamatani A, Ogura N, Katamoto N, Funakoshi M (1977) Seasonal variations of nutrients in Sagami Bay. In: Hogetsu $\mathrm{K}$, Hatanaka M, Hanaoka T, Kawamura T (eds) Productivity of biocenoses in coastal regions of Japan, JIBP synthesis 14. University of Tokyo Press, Tokyo, p 39-41

Kamatani A, Oku O, Tsuji H, Maeda M, Yamada Y (2000) The distribution and fate of nutrients in Sagami Bay. Nippon Suisan Gakkaishi 66:70-79 (in Japanese)

Karl D, Letelier R, Tupas L, Dore J, Christian J, Hebel D (1997) The role of nitrogen fixation in biogeochemical cycling in the subtropical North Pacific Ocean. Nature 388:533-538

Krom MD, Kress N, Brenner S, Gordon LI (1991) Phosphorus limitation of primary productivity in the eastern Mediterranean Sea. Limnol Oceanogr 36:424-432

Labry C, Herbland A, Delmas D (2002) The role of phosphorus on planktonic production of the Gironde plume waters in the Bay of Biscay. J Plankton Res 24:97-117

Legendre L, Demers S, Lefaivre D (1986) Biological production at marine ergoclines. In: Nihoul JCJ (ed) Marine interfaces ecohydrodynamics. Elsevier, Amsterdam, p 1-29

Miyaguchi H (2003) Occurrence and blooming mechanism of Noctiluca scintillans in the coastal waters of Sagami Bay, Japan. Masters thesis, Soka University, Tokyo

Nyholm N, Lyngby JE (1988) Algal bioassays in eutrophication research - a discussion in the framework of a mathematical analysis. Water Res 22:1293-1300

Peterson WT (1986) The effects of seasonal variations in stratification on plankton dynamics in Long Island Sound. In: Bowman MJ, Yentsch CM, Peterson WT (eds) Tidal mixing and plankton dynamics. Springer-Verlag, Berlin, p 297-320

Pitkänen H, Tamminen T (1995) Nitrogen and phosphorus as production limiting factors in the estuarine waters of the eastern Gulf of Finland. Mar Ecol Prog Ser 129:283-294

Rudek J, Paerl HW, Mallin MA, Bates PW (1991) Seasonal and hydrological control of phytoplankton nutrient limitation in the lower Neuse River Estuary, North Carolina. Mar Ecol Prog Ser 75:133-142

Ryther JH, Dunstan WM (1971) Nitrogen, phosphorus and, eutrophication in the coastal marine environment. Science 171:1008-1013

Satoh F, Hamasaki K, Toda T, Taguchi S (2000) Summer phytoplankton bloom in Manazuru Harbor, Sagami Bay, central Japan. Plankton Biol Ecol 47:73-79

Schindler DW (1977) Evolution of phosphorus limitation in lakes. Science 195:260-262

Smith REH, Harrison WG, Harris L (1985) Phosphorus exchange in marine microplankton communities near Hawaii. Mar Biol 86:75-84

Suzuki R, Ishimaru T (1990) An improved method for the determination of phytoplankton chlorophyll using N,Ndimethylformamide. J Oceanogr Soc Jpn 46:190-194

Sverdrup HU, Johnson MW, Fleming RH (1942) The oceans, their physics, chemistry and general biology. PrenticeHall, New York

Thingstad TF, Zweifel UL, Rassoulzadegan F (1998) P limitation of heterotrophic bacteria and phytoplankton in the northwest Mediterranean. Limnol Oceanogr 43:88-94

Toda T, Kikuchi T, Hamasaki K, Takahashi K, Fujiki T, Kuwahara V, Yoshida T, Taguchi S (2000) Seasonal and annual variations of environmental factors at Manazuru Port, Sagami Bay, Japan from 1995 to 1999. Actinia 13:31-41 (in Japanese)

Tsuda A, Sugisaki H, Takahashi K, Furuya K (1994) Succession of pelagic organisms in the size-range $0.5-200 \mu \mathrm{m}$ during a diatom bloom in Otsuchi Bay, Japan. Estuar Coast Shelf Sci 39:173-184 
Turner RE, Rabalais NN, Zhang ZN (1990) Phytoplankton biomass, production, and growth limitations on the Huanghe (Yellow River) continental shelf. Cont Shelf Res 10: 545-571

Turner RE, Rabalais NN, Justic D, Dortch Q (2003a) Global patterns of dissolved $\mathrm{N}, \mathrm{P}$ and $\mathrm{Si}$ in large rivers. Biogeochem 64:297-317

Turner RE, Rabalais NN, Justic D, Dortch Q (2003b) Fu-

Editorial responsibility: Otto Kinne (Editor),

Oldendorf/Luhe, Germany ture aquatic nutrient limitations. Mar Pollut Bull 46: 1032-1034

Venrick EL, Beers JR, Heinbokel JF (1977) Possible consequences of containing microplankton for physiological rate measurements. J Exp Mar Biol Ecol 26:55-76

Vincent WF (1981) Rapid physiological assays for nutrient demand by the plankton. II. Phosphorus. J Plankton Res 3:699-710

Submitted: February 24, 2003; Accepted: June 15, 2004

Proofs received from author(s): November 16, 2004 